\title{
LABILLARDIERE'S TASMANIAN LICHENS
}

\author{
by D.J. Galloway \\ (with nine plates)
}

GAllowaY, D.J., 1988 (31:x): Labillardière's Tasmanian lichens. Pap. Proc. R. Soc. Tasm. 122(2): 97-108. https://doi.org/10.26749/rstpp.122.2.97 ISSN 0080-4703. Department of Botany, British Museum (Natural History), Cromwell Road, London SW7 SBD.

Lichens from Terra Diemen (Tasmania) collected in 1792--93 by J.-J. H. Labillardière and now held in the Philip Barker Webb herbarium in Florence (FI-W) number 21 species in 13 genera preserved on 19 herbarium sheets. These include holotype and isotype material of Baeomyces reteporus Labill. [= Cladia retipora (Labill.) Nyl.], isolectotype material of Sticta billardiere Delise [= Pseudocyphellaria billardierei (Delise) Räsänen] and taxa from the following genera: Baeomyces, Cladia, Cladonia, Hypogymnia, Leptogium, Menegazzia, Parmelia, Parmelina, Pseudocyphellaria, Ramalina, Sphaerophorus, Stereocaulon and Usnea. These collections constitute the first known lichens from Tasmania. Brief notes, where applicable, accompany the species designations.

Key Words: Labillardière, lichens, Tasmania.

\section{INTRODUCTION}

Jacques-Julien Houtou de La Billardière was born in Alencon, Normandy on 28 October 1755 [Chevalier 1953, Carr \& Carr 1981 (not 23 October as given in Stafleu 1967:16)]. He abandoned use of his family name Houtou in 1791, subsequently using the shortened surname Labillardière (Carr \& Carr 1981). Labillardière studied medicine at Montpellier from 1772 onwards, learning botany there under Antoine Gouan (1733-1821), a friend of Philibert Commerson (1727-73), Boungainville's naturalist on the La Boudeuse and L'Étoile voyage of 1766-69. His medical studies were completed in Paris in 1780 when he met René Louiche Desfontaines (1750-1833), a life-long friend who was to become Professor of Botany at the Jardin des Plantes. In 1782 Labillardière visited England where he met Joseph Banks and James Edward Smith (Chevalier 1953, Stafleu 1967), both later to be of considerable service to him in 1796 when his Southern Hemisphere plant collections were eventually returned to Paris, after their initial seizure by the Dutch and subsequent capture as a Royal Navy prize (see below). Labillardière studied plants in Syria and Lebanon (including present-day Palestine and Jordan) between 1787 and 1789, his published work on his collections Icones plantarum Syriae rariorum being illustrated by Pierre-Joseph Redouté.

With the help and influence of his scientific patron in Paris, Louis Guillaume Le Monnier
(1717-99), pupil of de Jussieu and Professor of Botany at the Jardin du Roi (1758-86), Labillardière was appointed one of three naturalists on the ships La Recherche and L'Espérance under the command of Joseph Antoine Bruni D'Entrecasteaux (1739-93), charged by the Assemblée Constituante on 9 February 1791 to search for the lost expedition of Jean Francois de Galaup, comte de la Pérouse (1741-88). The two ships left France at the end of September 1791 and, after calling at Tenerife and the Cape of Good Hope, made landfalls in Australia including Tasmania (see below). During this time Labillardière made copious botanical collections, many of which he later described (Labillardière $1800,1807)$. The fate of the expedition and the deaths of its two senior officers, D'Entrecasteaux and Huon de Kermadec, is amply recounted elsewhere (Stafleu 1967, Carr \& Carr 1976, 1981).

After briefly considering Labillardière's collecting sites during his Australian landfalls, and also the subsequent fate of his natural history collections after their capture by the Dutch in Java in 1794, this paper records the lichens collected by Labillardière in Tasmania, now preserved in the Philip Barker Webb Herbarium in Florence. Labillardière has an established place in the annals of Australian and South Pacific lichenology, for his description of Baeomyces reteporus (Labillardic̀re 1807), the first published account of an Australian lichen (see Wetmore 1963, Filson 1976, 1986, Kantvilas 1983, Galloway 1985b). 


\section{LABILLARDIÈRE'S COLLECTING LOCALITIES}

The south coast of Tasmania was first visited by D'Entrecasteaux and his expedition between March and May 1792, after a weary sea voyage from the Cape. Landings were made at "D'Entrecasteaux Bay" and at "North Bay", inlets of Recherche Bay (Nelson 1974, Carr \& Carr 1976 and Ducker 1979 give the Tasmanian locality as Storm Bay). Labillardière wrote of the new landscape:

"It is difficult to express the sensations we felt, at finding ourselves at length sheltered in this solitary harbour at the extremity of the globe, after having been so long driven to and fro in the ocean by the violence of the storms ..." (Labillardière 1800 Vol.I: 158).

There can be no doubt that the country and its natural history as well as the native people made an enormous impact on Labillardière, as a reading of his book shows, and two short extracts capture something of his sense of wonder:

"In the afternoon I went ashore, accompanied by the gardener and two others of our ship's company, in order to make an excursion into the country towards N.E. We were filled with admiration at the sight of these ancient forests, in which the sound of an axe had never been heard ... The most luxuriant vigour of vegetation is here contrasted with its final dissolution, and presents to the mind a striking picture of the operations of nature, who, left to herself, never destroys but that she may again create" (Labillardière 1800 Vol.I: 170 ).

The ships spent some 22 days at anchor near Recherche Bay during which time Labillardière and the other naturalists had plenty of opportunities for exploration and collection (Giblin 1928, Nelson 1974, 1975, Carr \& Carr 1976). Tasmania was visited again between 24 January and 15 February 1793, Labillardière noting:

"The whole of the 26th [January] I spent describing and preparing every thing I had collected since our arrival in Rocky Bay. I was astonished at the great variety of productions still afforded me by this part of New Holland, where I had been very diligent in my researches for more than a month the preceding year ... (Labillardière 1800 Vol.II: 13)

"We had planned a visit to the highest mountains in this part of New Holland, the various sites of which gave us hopes of a great number of new productions ..."
Camping at night in the open Labillardière observed:

"The air was extremely calm; and about midnight I awakened, when, solitary in the midst of these silent woods, the majesty of which was half disclosed to me by the feeble gleam of the stars, I felt myself penetrated with a sentiment of admiration for the grandeur of nature, which it is beyond my powers to express" (Labillardière 1800 Vol.II: $22-23$ )

Nelson $(1974,1975)$ and Carr \& Carr (1976) gave further information on Labillardière's collecting sites in Tasmania and at Esperance Bay, Western Australia, and also draw attention to the fact that several of the plants described by Labillardière (1807) could not have been collected on his own travels. These specimens undoubtedly came into his hands from the botanists of the Géographe and Naturaliste voyage under Nicolas Baudin, one of whom (Leschenault de la Tour) was the presumed collector of Sticta delisea Delise [=Pseudocyphellaria glabra (J.D. Hook. \& Taylor) Dodge] (see Galloway 1988, Galloway \& James 1986). Nearly all of the lichens discussed below are from "Terra Dieman" (Tasmania), and it is assumed that they were collected by Labillardière from one of the Tasmanian landfalls of 1792-93, although two putative Labillardière collections from Fée's herbarium may very possibly be from collections made in Esperance Bay, Western Australia. Nelson (1974), Carr \& Carr (1976) and Ducker (1979) all gave Storm Bay as the Tasmanian locality corresponding to "Capite van Diemen" of Labillardière's autograph, and published descriptions in the Specimen. However, Giblin (1928) mentioned D'Entrecasteaux Bay and North Bay, both inlets of Recherche Bay at the southern end of D'Entrecasteaux Channel and close to South East Cape, while Kantvilas (1983) stated:

"The localities he [Labillardière] would probably have visited range from Recherche Bay and D'Entrecasteaux Channel to Storm Bay and the Derwent River estuary as far as Glenorchy Rivulet."

\section{THE FATE OF LABILLARDIÈRE'S COLLECTIONS}

On leaving Tasmania in 1793, the expedition travelled north via the Santa Cruz and Admiralty Islands to Java. During the voyage both D'Entrecasteaux and his succeeding officer, Huon 


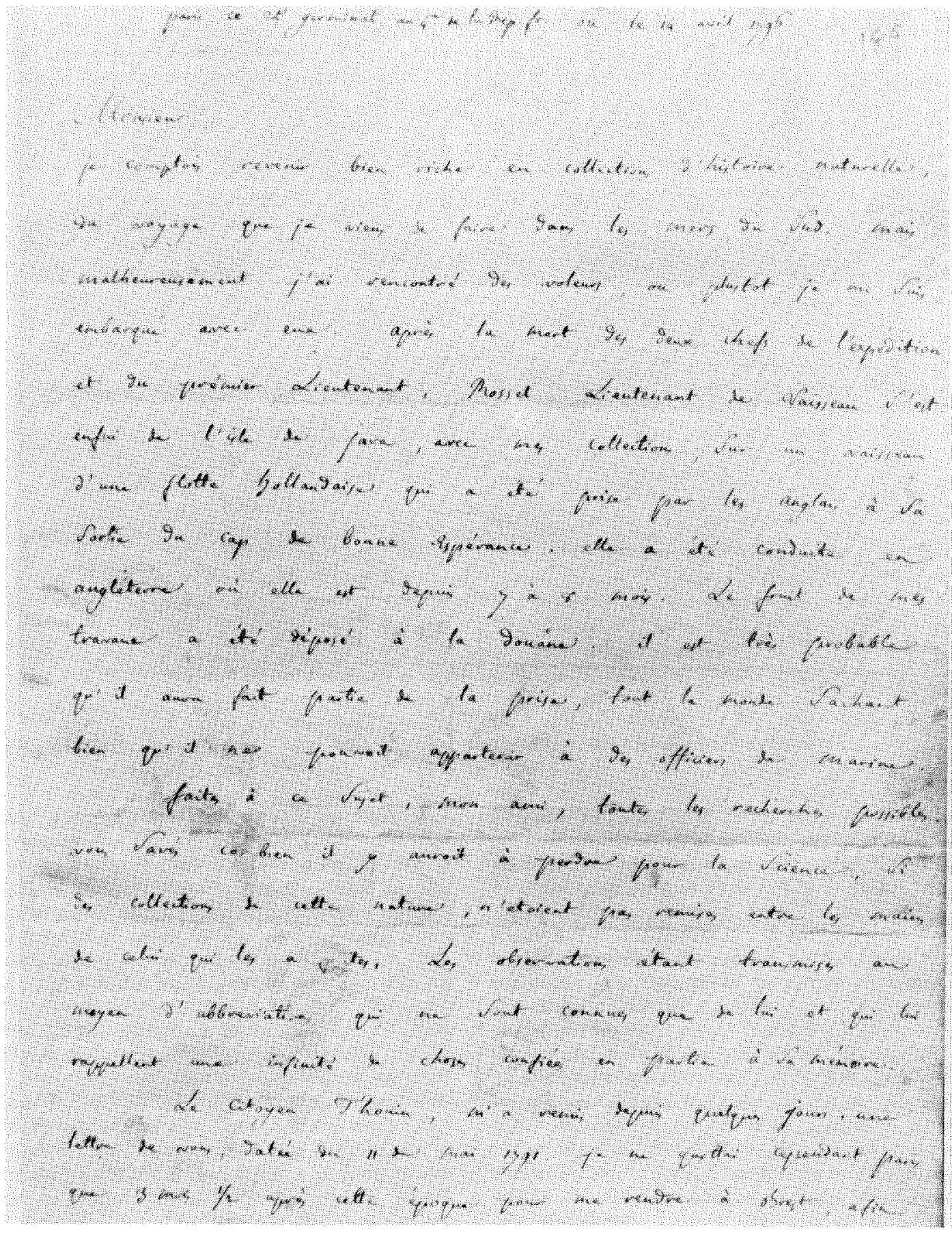

PLATE 1

First page of letter from Labillardiere to James Edward Smith, 14 April 1796. Smith Papers (1: 189): Archives, Linnean Society of London. 


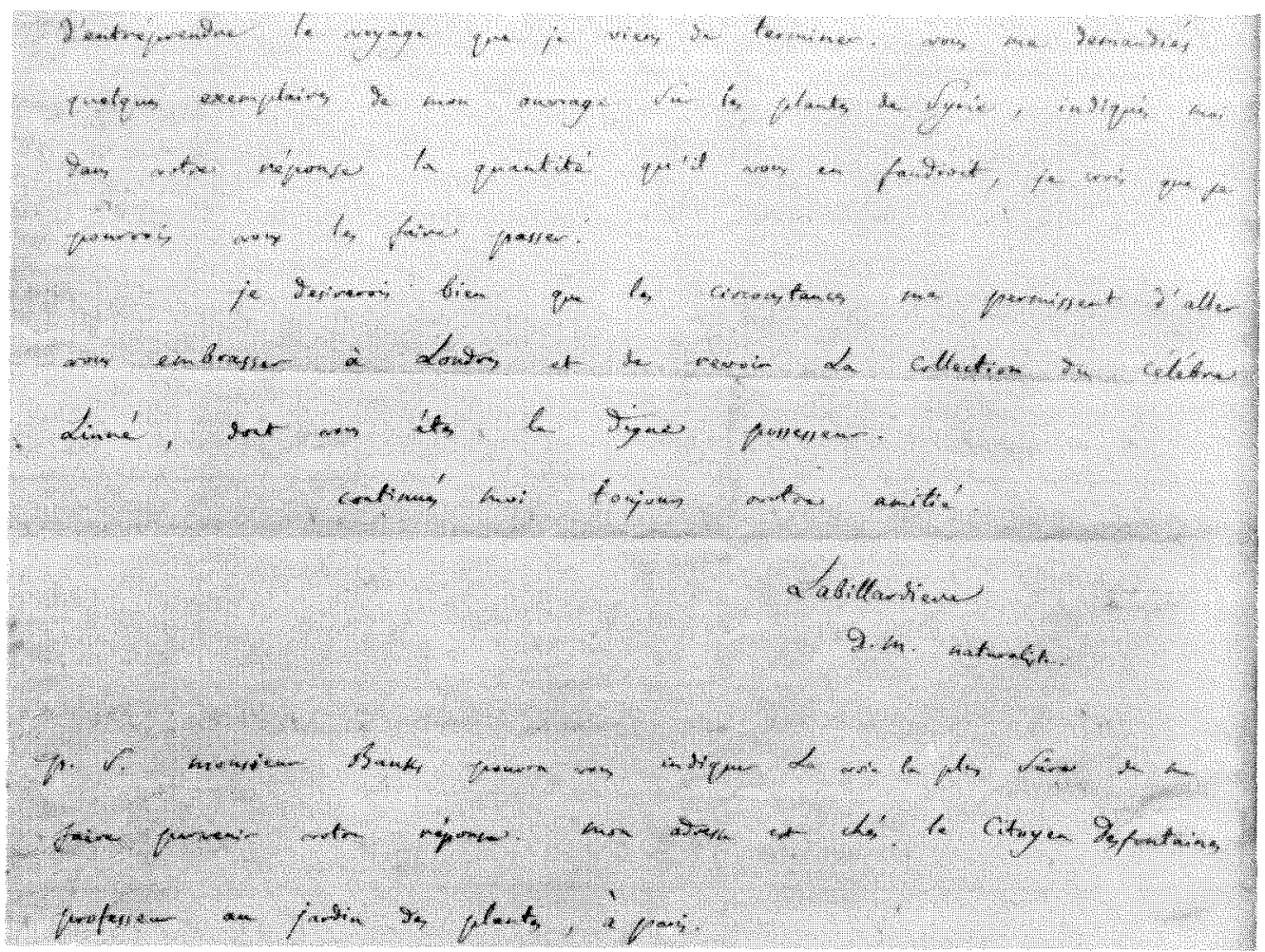

PLATE 2

Second page of letter from Labillardière to JamesEdward Smith, 14 April 1796. Smith Papers (1: 189): Archives, Linnean Society of London.

de Kermadec, died at sea. Command then devolved upon Alexander Hemisvy D'Aribeau who took the ships to Java where they learned of the execution of Louis XVI and of the Dutch being at war with France. Republican members of the ship's company, including Labillardière, were taken prisoner, whilst a number of the Royalist officers under the command of Rossel, who succeeded D'Aribeau on the latter's death, were allowed safe passage to France taking the expedition's (Labillardière's) collections with them (see Nelson 1975, Carr \& Carr 1976, 1981). Although losing his collections, Labillardière retained his journal and eventually returned to France in 1796. Meanwhile, in June 1795, the Dutch vessel Hooghly, with Rossel and Labillardière's collections aboard, was captured by the British Navy in the Atlantic, 15 days after leaving the Cape. As the British and Dutch were also at war, Labillardière's collections were claimed by the British as a naval prize and taken to London to be lodged in the Customs House.
Although France and Britain were at war, their men of science were not. On Labillardière's return to Paris he wrote to both Sir Joseph Banks and to James Edward Smith (founder of the Linnean Society of London, and then owner of the Linnaeus collection), both of whom he had met in 1782 and corresponded with since, enquiring about the fate of his collections. Labillardière's letter to Smith (plates 1 and 2) is an eloquent plea for the return of the collections to France and to their rightful owner. The praiseworthy role of Sir Joseph Banks in the safe return of the collection to Paris is well documented (De Beer 1952, 1960, Stafleu 1967, Carr \& Carr 1981), and Labillardière later (5 March 1800) sent Banks a copy of his Relation du voyage à la recherche de la Pérouse, with his thanks for having secured the return of his collections (Dawson 1958).

Labillardière's preparation of his collections for publication, and the publication of Novae Hollandiae plantarum specimen is dealt with in some detail by Stafleu (1967) who noted that 


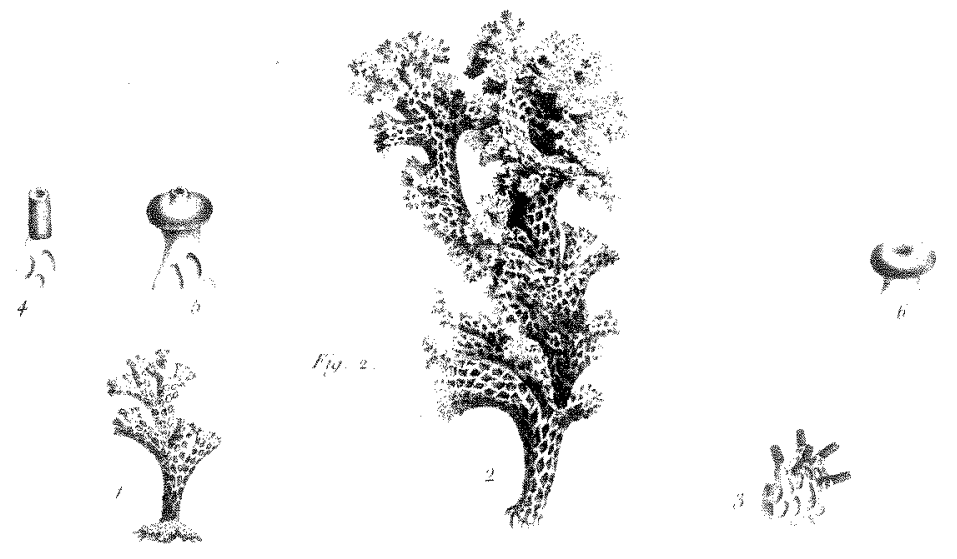

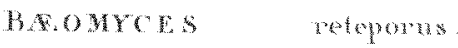

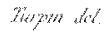

(2)

Antert werly,

PLATE 3

Turpin's drawings of Baeomyces reteporus from Labillardière's Novae Hollandiae plantarum specimen.

Labillardière "never really worked up all his collections" being more of a "'botanist-voyageur' with the emphasis on "voyageur". Be that as it may, Labillardière did leave us the first formal description of an Australian lichen, and this singularly beautiful lichen is perfectly caught by Pierre Jean Francois Turpin's illustration in the Specimen (plate 3). Blunt (1950) described Turpin as "possibly the greatest natural genius of all the French botanical painters of his day". It is therefore fitting that a singular lichen should have a singular artist to first present its interest and beauty to the world. In 1834, Labillardière's plant collections were purchased by the wealthy English amateur botanist Philip Barker Webb (1793-1854). Webb lived for many years in Paris, where he was a close friend and colleague of Montagne, who determined much of his cryptogamic material including the Labillardière lichens, and during the last 14 years of his life often worked in Florence. Webb willed his enormous herbarium, his library and his house in Paris to the Grand Duke Leopoldo I of Tuscany in 1850 , with the intention that the collections be added to the Erbario Centrale Italico, now the Herbarium Universitatis Florentinae (FI) of the University of Florence. The Webb Herbarium
(FI-W) contains almost all of the holotypes of species Labillardière described from the Lebanon, Australia and New Caledonia. The holotypes are nearly always accompanied by the holograph description, in the exact text as published (Steinberg 1977). The holotype of Baeomyces reteporus has such an holograph description (plates 4 and 5), with isotype material also known in the British Museum of Natural History (BM) and the Museum National d'Histoire Naturelle, Laboratoire de Cryptogamie (PC) (see Wetmore 1963, Stafleu \& Cowan 1979, Filson 1981). Labillardière's long-forgotten remaining Tasmanian lichens are detailed below for the first time since their discovery.

\section{METHODS AND MATERIALS}

Labillardière's Tasmanian lichens in FI-W (nomenclature follows Holmgren et al. 1981) are attached to paper sheets $(46 \times 27 \mathrm{~cm})$ which have in the bottom left-hand corner a printed label $(9.5 \times 6.5 \mathrm{~cm})$ stating "Herb. Webbianum. Ex Herb. Labillardière", with "Terra Diemen" added in most cases in ink (plate 6). Thin-layer chromatography 


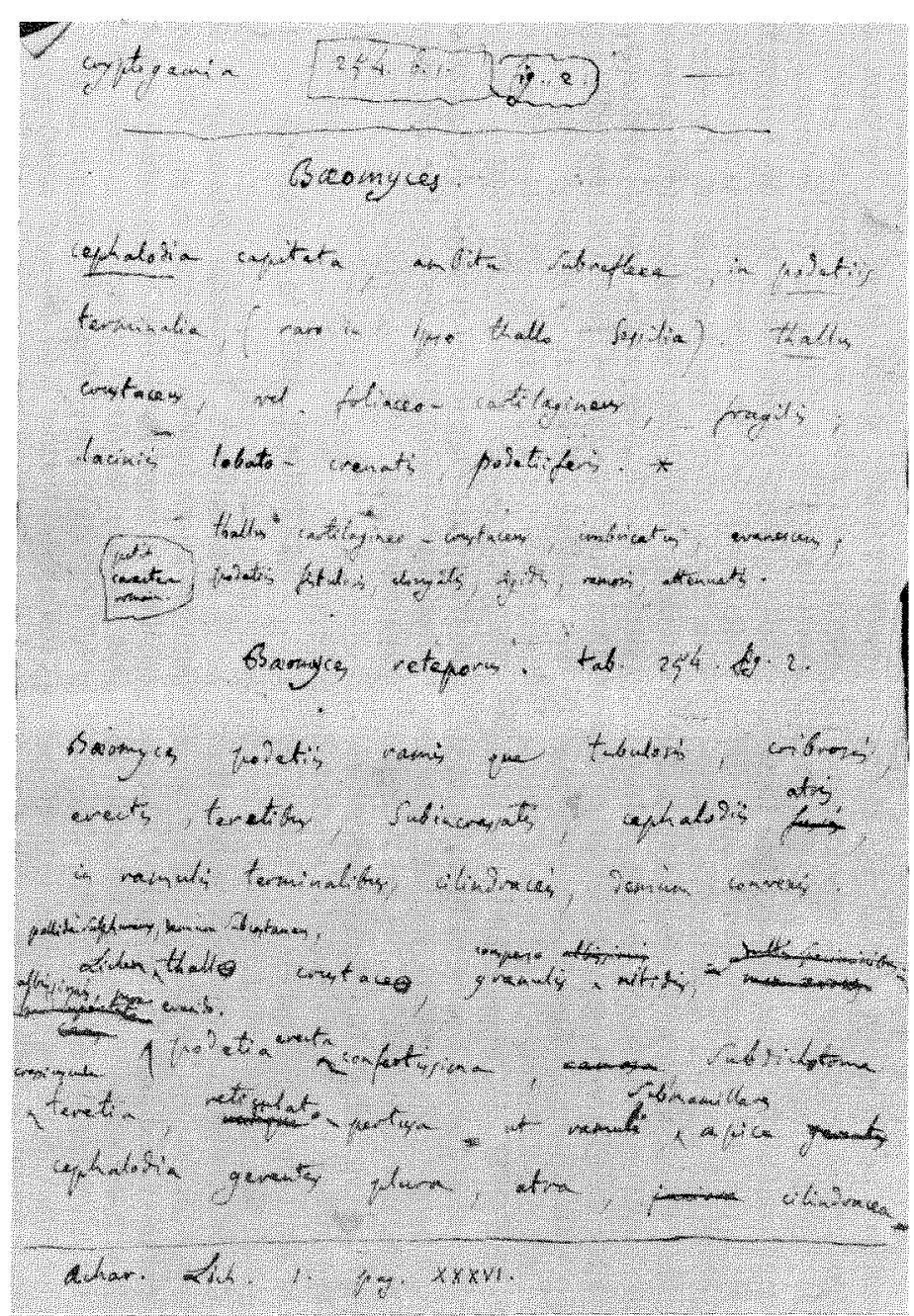

PLATE 4 Labillardière's autograph description of Baeomyces reteporus; recto $(F I-W)$.

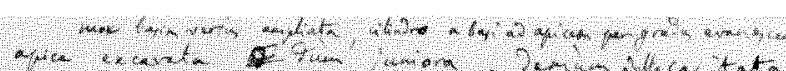

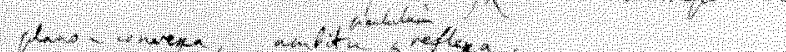

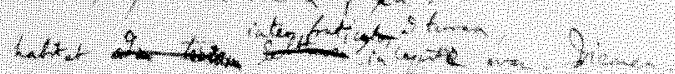

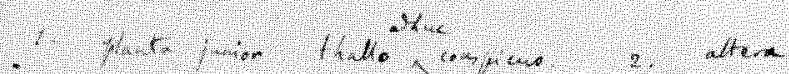

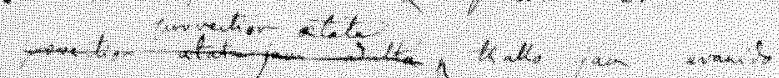

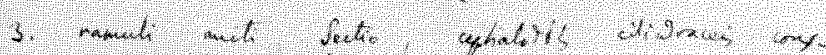

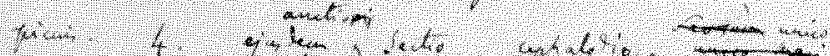

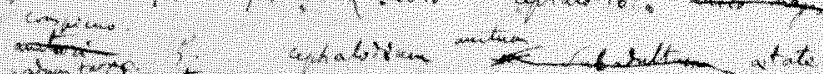

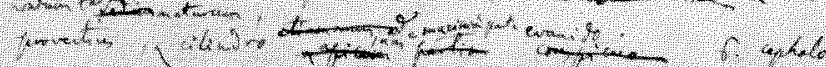

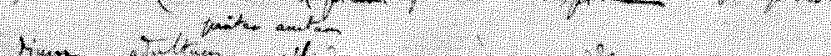

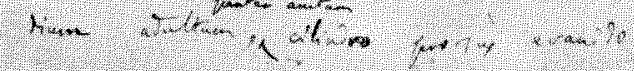

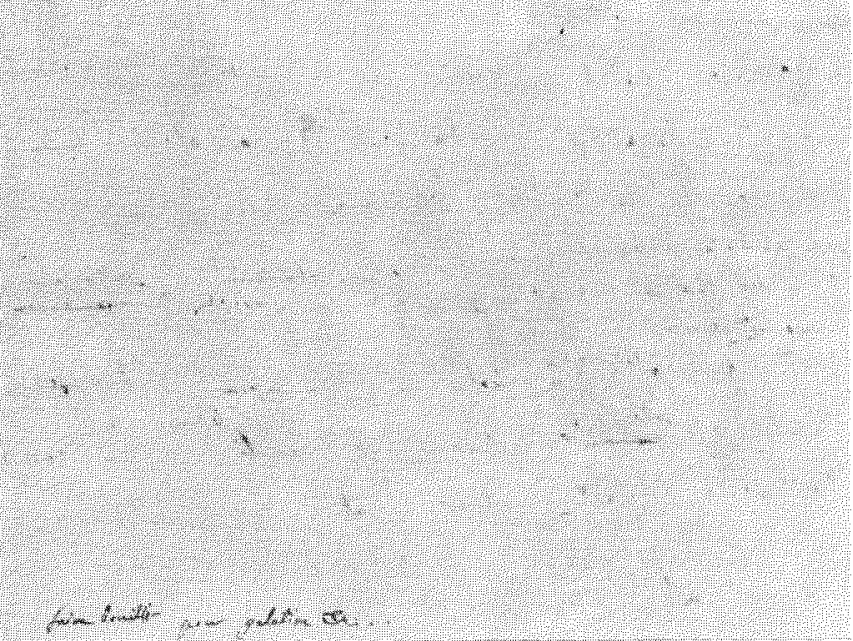

PLATE 5 Labillardière's autograph description of Baeomyces reteporus; verso $(F I-W)$. 


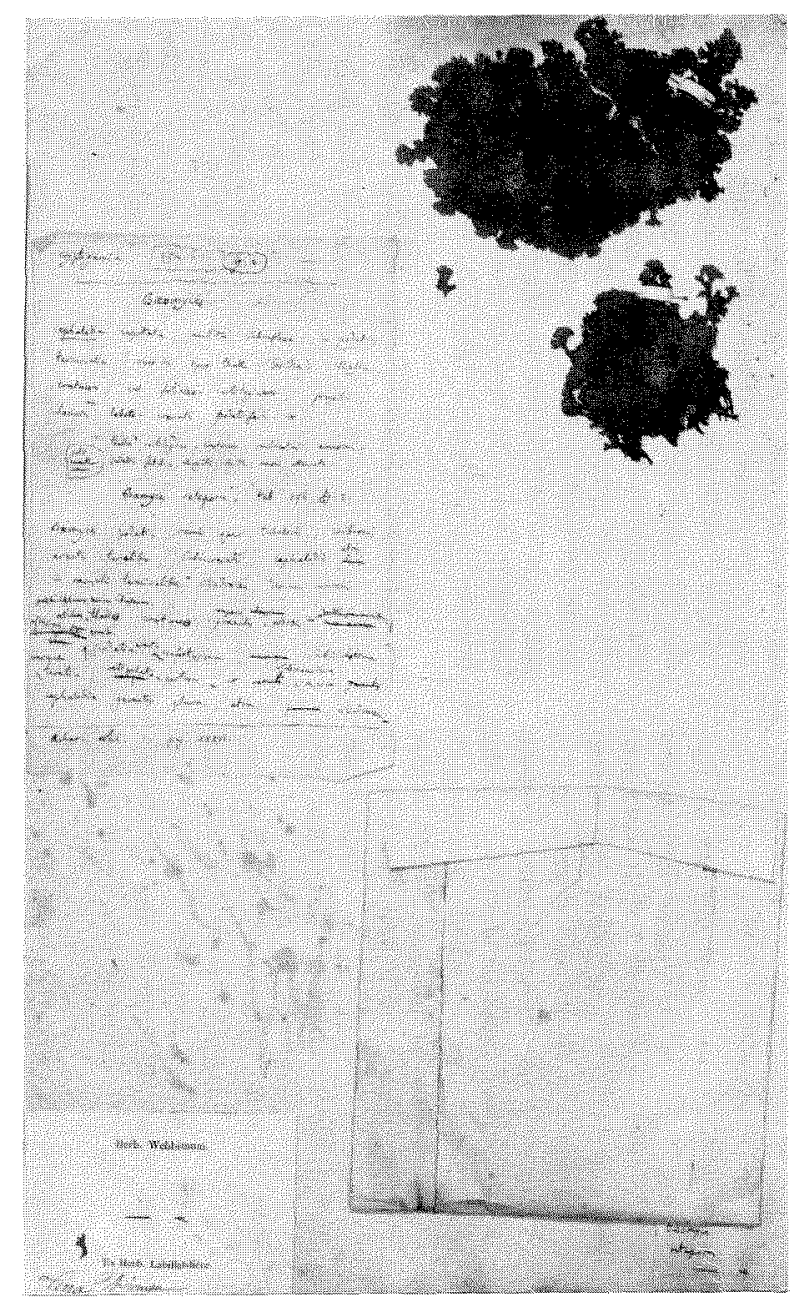

PLATE 6 Holotype of Baeomyces reteporus Labill. (FI-W).

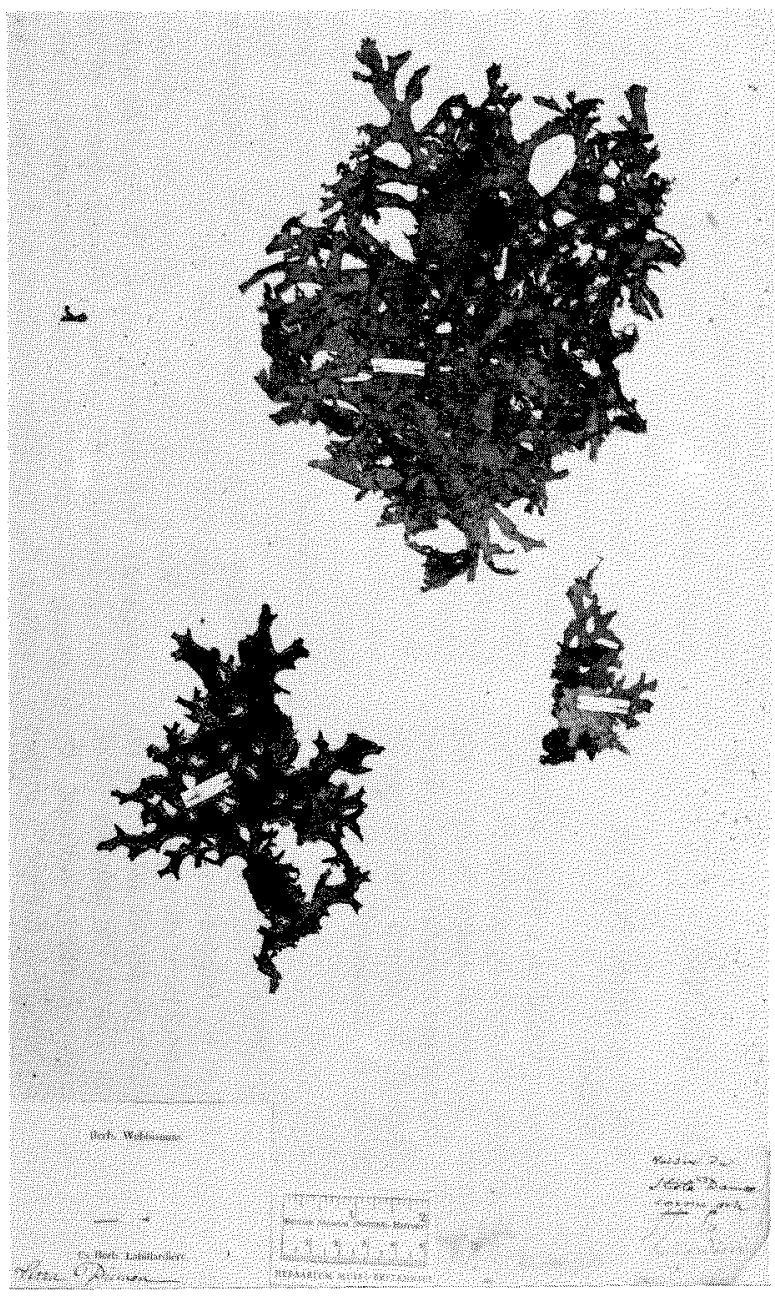

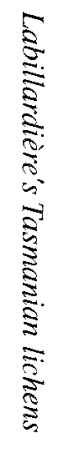

PLATE 7 Isolectotype of Sticta billardierei Delise (FI-W) 
(TLC) of acetone extracts of specimens was carried out using standardised methods (White \& James 1985).

\section{THE SPECIES}

(1) Baeomyces heteromorphus Nyl. ex Church. Bab. \& Mitten

Two packets are pinned to a sheet which is labelled by Montagne "Biatora byssoidea Fr.". The first packet contains $B$. heteromorphus overgrowing bryophytes, while the second contains small pieces of clay, much abraded, to which the lichen is attached. The species is discussed in Galloway (1980).

\section{(2) Cladia aggregata (Swartz) Nyl.}

One sheet, labelled by Montagne "Cladonia aggregata Spr.", has 21 specimens of a robust form of this lichen glued to two pieces of paper, 18 on the upper piece, 3 on the lower. On another sheet, material of Cladia aggregata (annotated by Montagne as "Cladonia aggregata Eschw.") occurs with specimens of Sphaerophorus tener. Another specimen of $C$. aggregata from Fée's herbarium (Flore de la Nouvelle Hollande) is annotated in Fée's hand "Cladonia australia Fée récolté par La Billardière" to which Montagne has added "Compre da Fée in Maggio 1854". The species is discussed in Filson (1981).

\section{(3) Cladia retipora (Labill.) Nyl.}

Material of this taxon is distributed on two herbarium sheets. What is designated here as the holotype of Baeomyces reteporus Labill. (plate 6) has two specimens $(11 \times 8 \mathrm{~cm}$ and $6 \times 6 \mathrm{~cm})$ pinned to the sheet on the top right-hand corner, and a paper packet containing several additional pressed specimens on the lower right-hand corner of the sheet. A small paper label marked "Baeomyces reteporus" in Labillardière's hand is pinned below this packet. Accompanying the lichen specimens is a single loose octavo sheet of paper written in ink on both sides in Labillardière's hand. The recto (plate 4) has a description of Baeomyces and part of the description of the new species Baeomyces reteporus, while the verso (plate 5) has the remainder of the species description as well as legends for the figure illustrating the species in Novae Hollandiae Plantarum Specimen Vol.II (plate 3).

Filson (1981: 23 and fig. 16b) designated material in Paris (PC) as lectotype without having seen the Labillardière herbarium in FI-W. Later, he designated the FI-W collections and additional PC material as isolectotypes (Filson 1986: 24-5). However, the presence of rich typical material together with Labillardière's holograph description amply qualify the FI-W material as holotype of Baeomyces reteporus (Art. 8.1). The PC material should therefore now be considered as isotype.

Additional isotype material exists on another sheet in FI-W and comprises a small specimen in a paper packet having an attached label in Labillardière's hand "Baeomyces reteporus Labill., n.holl. pl.Spec. t. 255. f.2". Further isotype specimens exist in BM (one labelled "baeomyces reteporus nh. pl.Spec. tab. 254" in Labillardière's hand, and another labelled "Dr Smith from M.Labillardière. New Holland", and one in LINNSM 1710.17 (labelled in Smith's hand "New Holland. M.La Billardière, 1807. Baeomyces reteporus Bill. Specn. t. 254. f.2").

Writing of Cladia retipora (as Cenomyce retipora), W.J. Hooker stated "Nothing in nature can exceed the elegant lace-like appearance of this plant, a structure one would little expect to meet with in the humblest and least perfect part, as it is usually considered, of the vegetable creation, the Lichens. Labillardière, and following him, Acharius, ascribe a thallus to this species ... but my copious specimens exhibit no appearance of a thallus. If it exists, it is probably very evanescent ... The texture of the entire plant is, as it were, between crustaceous and cartilaginous, not much unlike that of our well-known Cenomyce rangiferina; but, instead of forming an uniform tubular membrane, the whole surface is a tissue of elegant network, the areolae oval or rounded, varying somewhat in size, but gradually becoming smaller in the ultimate small ramuli; then the inside, instead of being tubular, is filled with the same tissue of network anastomosing in every direction from the base to the summit of all the branches ..." (Hooker 1842).

\section{(4) Cladonia scabriuscula (Delise) Leighton}

Material (a small collection of 3-4 podetia) referable to this species is pinned to a sheet, and is annotated "Cladonia furcata Hoffm." in Montagne's hand. A small packet pinned to the base of the same sheet contains Stereocaulon ramulosum and has an associated label. "Stereocaulon Cenomyce furcata var. monstrosa" in Philip Barker Webb's hand. 


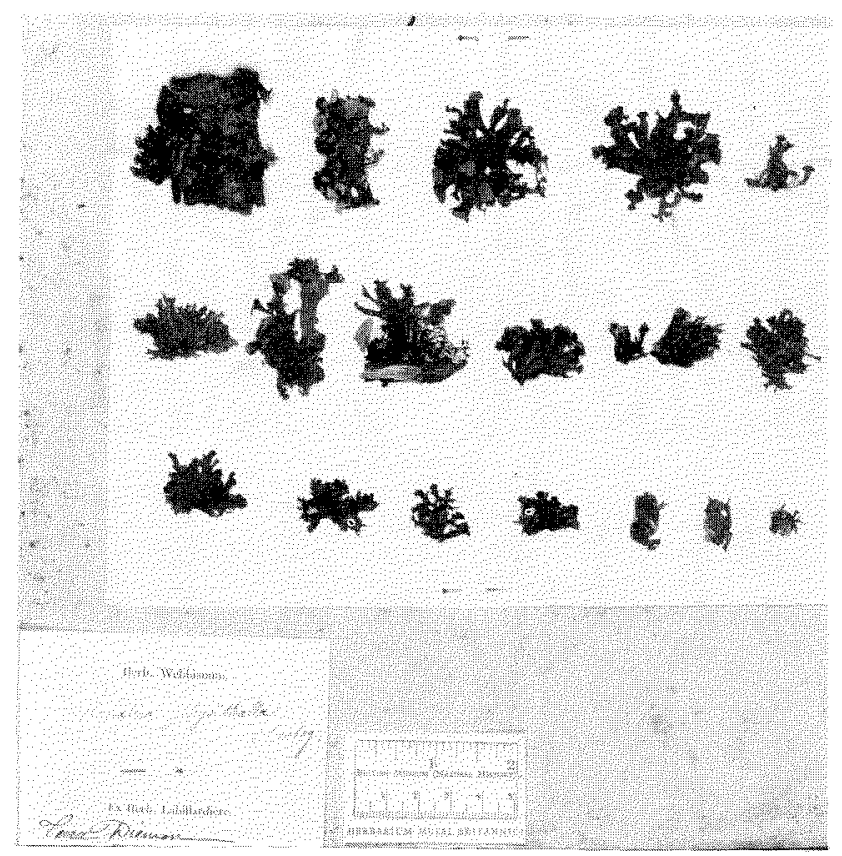

PLATE 8

Labillardière's collection of Ramalina inflata (JD. Hook. \& Taylor) J.D. Hook. \& Taylor, annotated "Ramalina physithalla" by Montagne (FI-W).

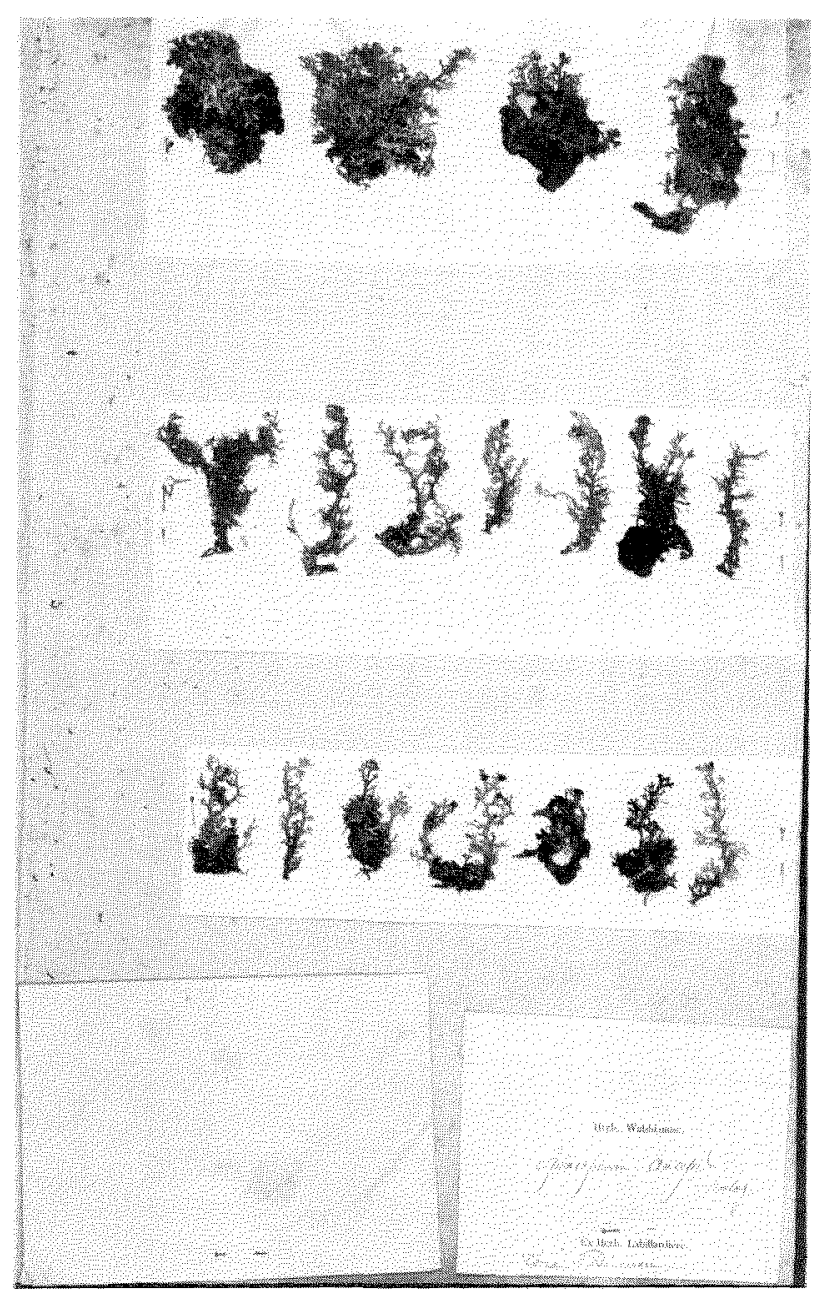

PLATE 9

Labillardière's collection of Sphaerophorus ramulifer Lamb, annotated "Sphaerophoron anceps" by Montagne (Fl-W). 


\section{(5) Cladonia southlandica W. Martin}

Eight specimens of this characteristic species are glued to a sheet which is annotated in Montagne's hand "Cladonia australasica Montag." with a previous epithet "Billardieri" crossed out. Neither of these herbarium names were subsequently used by Montagne. The species is discussed by Martin (1962), Ahti (1973) and Galloway (1985a).

\section{(6) Hypogymnia turgidula (Bitter) Elix}

Eight specimens attached to small twigs are pinned to a sheet. The species is discussed by Elix (1979). The sheet also contains a specimen of a fertile, non-sorediate Menegazzia, referable to $M$. weindorferi, and a small specimen of $M$. caesiopruinosa.

\section{(7) Leptogium azureum (Swartz) Mont.}

Two specimens are glued to a sheet labelled "Collema azureum Ach.". The species is discussed by Jørgensen \& James (1983) and Galloway (1985a).

\section{(8 Menegazzia caesiopruinosa P. James}

This species is described and discussed in Kantvilas \& James (1987: 25). See above under Hypogemnia turgidula.

(9) Menegazzia weindorferi (Zahlbr.) R. Sant.

This species is common in open forest habitats in Tasmania (Kantvilas et al. 1985. Kantvilas \& James 1987). See above under Hypogymnia turgidula.

\section{(10) Parmelina stevensiana Elix \& Johnston}

See below under Ramalina inflata. The species is described and discussed by Elix \& Johnston (1986).

(11) Parmelia tenuirima J.D. Hook. \& Taylor

See below under Sphaerophorus tener. The species is discussed by Galloway \& Elix (1983), Galloway (1985a) and Hale (1987).

(12) Pseudocyphellaria billardierei (Delise) Räsänen

Three specimens $(18 \times 12 \mathrm{~cm}, 13 \times 9 \mathrm{~cm}$ $7 \times 3 \mathrm{~cm})$ are pinned to a sheet which is annotated by Philip Barker Webb "voisin du Sticta Damaecornu Ach. Sticta billardieri" (plate 7). The material is without doubt of the same provenance as the lectotype specimen from Delise's herbarium in PC-LENORMAND (Galloway 1985a, 1988 , Galloway \& James 1986, Galloway et al. 1983), but is larger and in slightly better condition. The FI-W material is therefore isolectotype (Galloway 1988: 75)

(13) Pseudocyphellaria multifida (Nyl.) D. Galloway \& P. James

Five small specimens are pinned to a sheet (their sizes range from $9 \times 8 \mathrm{~cm}$ to $4 \times 3 \mathrm{~cm}$ ), one of them being attached to a small twig. Montagne has labelled the collection Sticta Labillardierii Delise" and another hand has written "Sticta rigidula Delise" (the latter annotation is possibly by Delise). However, the material is neither of these species, but typical Pseudocyphellaria multifida, a common Tasmanian forest epiphyte (Kantvilas \& James 1987, Galloway 1988). A specimen of this material also exists in PC-MONTAGNE (Galloway et al. 1983: 141). This species was formerly recorded as Pseudocyphellaria subvariabilis (Galloway et al. 1983, Galloway 1985a, Kantvilas et al. 1985, Kantvilas \& James 1987).

(14) Ramalina inflata (J.D. Hook. \& Taylor) J.D. Hook. \& Taylor

Nineteen specimens are glued to one sheet, two of them being attached to bark, the remainder free. The larger piece of bark has a small specimen of Parmelina stevensiana also attached. The sheet is annotated in Montagne's hand "Ramalina physithalla Montag." (plate 8), an unpublished herbarium name. Another sheet has five specimens of Ramalina inflata attached to small twigs, while an additional sheet has two pieces of bark containing Ramalina inflata and Parmelina stevensiana. Ramalina inflata is discussed by Stevens (1987).

\section{(15) Sphaerophorus ramulifer Lamb}

A sheet labelled "Sphaerophoron anceps Montag." (plate 9) in Montagne's hand (an unpublished herbarium name) has 18 specimens of Sphaerophorus ramulifer glued to it and two packets pinned separately. This species is commonly represented in open rainforest in Tasmania (Kantvilas et al. 1985), and is discussed by Tibell (1987). 


\section{(16) Sphaerophorus tener Laurer}

Three specimens are attached to a sheet which also includes scraps of Parmelia tenuirima. The sheet has a small annotation label on the righthand lower edge marked "Sphaerophoron fragile affinis" in pencil. The species is discussed by Tibell (1987).

\section{(17) Stereocaulon ramulosum (Swartz) Räuschel}

See above under Cladonia scabriuscula.

\section{(18) Usnea cf. angulata Ach.}

A large specimen $(33 \mathrm{~cm})$ containing protocetraric and usnic acids plus three unidentified compounds, is labelled "Usnea longissima Ach." in Montagne's hand.

\section{(19) Usnea molliuscula Stirton}

Ten small specimens of this species are glued to a sheet containing specimens of Usnea oncodes and $U$. scabrida, and labelled by Montagne as "Usnea leucocarpa Delise". One example is attached to a sheet containing Usnea oncodes and $U$. scabrida, labelled "Usnea strigosa Pers." by Montagne.

\section{(20) Usnea oncodes Stirton}

Five specimens of this characteristic sorediate species, together with five specimens of Usnea scabrida and ten specimens of $U$. mollinscula, are glued to a sheet labelled by Montagne "Usnea leucocarpa Delise". A further specimen is attached to a sheet labelled "Usnea strigosa Pers." by Montagne.

\section{(21) Usnea scabrida Taylor}

Five specimens are present on a sheet annotated by Montagne "Usnea strigosa Pers.", and five are present on a sheet labelled "Usnea leucocarpa Delise" by Montagne. All three species of Usnea mentioned above contain salazinic and usnic acids.

\section{ADDITIONAL NOTES}

\section{(1) Hypogymnia billardierei (Mont.) Filson}

Material labelled "Parmelia billardieri Fée, sur les Casuarinas récolté par LaBillardière" in Fée's hand is possibly type material of Cetraria billardierei Mont. [= Hypogymnia billardieri (Mont.) Filson]. The specimen is glued to a card which has Montagne's annotation "Compr da Fée in Maggio 1854". Fée's printed label is headed "Herbier de Fee. Flore de la Nouvelle Hollande". Hypogymnia billardierei is discussed by Elix (1979) who stated that it is widespread on bark, twigs of trees and dead wood in dry sclerophyll forests of New South Wales, Victoria and Tasmania, but is rather rare in South Australia. It is not certain whether this material from Fée's herbarium is from Tasmania or from the mainland of Australia, or whether in fact it is a genuine Labillardière collection.

(2) Pseudocyphellaria neglecta (Müll. Arg.) H. Magnusson

Material from Fée's herbarium (Flore de la Nouveile Hollande) is annotated by Fée "Sticta australis Fée, sur les Casuarinas. Récolté par LaBillardière", to which Montagne has added "Compr. da Fée in Maggio 1854". Again, it is not certain whether this is a Tasmanian or mainland Australian collection, and doubt as to its provenance must be entertained until further Fée material is seen. This material, ascribed by Fée to Labillardière, may prove to be part of a later collection made by botanists on the expedition commanded by Nicolas Baudin (e.g. Leschenault de la Tour) which has in the past been confused with material collection by Labillardière (Nelson 1974, 1975, Carr \& Carr 1976, Galloway \& James 1986).

\section{ACKNOWLEDGEMENTS}

I am grateful to Prof. G. Moggi (Florence) for the loan of material from the Philip Barker Webb Herbarium; to Mr P.W. James (BM) for helpful discussions on a draft of this paper; to Ms G. Douglas, Librarian and Archivist of the Linnean Society of London for access to the J.E. Smith Archive; and to $\mathrm{Mr}$ D.B. Adams and $\mathrm{Mr} \mathrm{C.B.}$ Keates (BM) for expert photographic assistance.

\section{REFERENCES}

AHTI, T., 1973: Taxonomic notes on some species of Cladonia subsect. Unciales. Annls bot. fenn. 10: 163-184.

BLUNT, W., 1950: THE ART OF BOTANICAL ILLUSTRATION. Collins, London.I

CARR, S.G.M. \& CARR, D.J., 1976: The French contribution to the discovery of Australia and its flora. Endeavour 35: 21-26.

CARR, S.G.M. \& CARR, D.J., 1981: A charmed life. The collections of Labillardiere. In Carr, D.J. \& 
Carr, S.G.M. (Eds): PEOPLE AND PLANTS IN AUSTRALIA. Academic Press, London: 79-115.

CHEVALIER, A, 1953: Un grand voyageur naturaliste normand J.-J. La Billardière (1755-1834). Rév. Int. Bot. Appl. Agr. Trop. 33: 97-124, 185-202.

DAWSON, W.R., 1958: THE BANKS LETTERS. British Museum (Natural History), London.

DE BEER, G.R., 1952: The relations between Fellows of the Royal Society and French men of science when France and Britain were at war, Notes Rec. R. Soc, 9: 244-299.

DE BEER, G.R., 1960: THE SCIENCES WERE NEVER AT WAR. Thomas Nelson, London: 45-68.

DUCKER, S.C., 1979: History of Australian phycology: the significance of early French exploration. Brunonia 2: 19-42.

ELIX, J.A., 1979: A taxonomic revision of the lichen genus Hypogymnia in Australia. Brunonia 2: $175-245$.

ELIX, J.A. \& JOHNSTON, J, 1986: New species of Parmelina (lichenised Ascomycotina) from Australia and New Zealand. Brunonia 9: $155-161$.

FILSON, R.B., 1976: Australian lichenology: a brief history. Muelleria 3: 1830190

FII..SON, R.B., 1981: A revision of the lichen genus Cladia Nyl. J. Hattori Bot. Lab. 49: 1-75.l

FILSON, R.B., 1986: INDEX TO TYPE SPECIMENS OF AUSTRALIAN LICHENS: 1800-1984. Austr. Faun. Fl. Ser. 4. Canberra.

GALLOWAY, D.J., 1980: Notes on the lichen genus Bacomyces in New Zealand. Bot. Notiser 133: 77-83.

GALLOWAY, D.J., 1985a: FLORA OF NEW ZEALAND LICHENS. New Zealand Government Printer, Wellington.

GALLOWAY, D.J., 1985b: Lichenology in the South Pacific, 1790-1840. In Wheeler, A. \& Price, J.H. (Eds): FROM LINNAEUS TO DARWIN: COMMENTARIES ON THE HISTORY OF BIOLOGY AND GEOLOGY Soc. Hist. nat. Hist. Special Vol. 3: 205-214.

GALLOWAY, D.J., 1988: Studies in Pseudocyphellaria (lichens) I. The New Zealand species. Bull. Br Mus. nat. Hist. (Bot.) 17: 1-267.

GALLOWAY, D.J. \& ELIX, J.A., 1983: The lichen genera Parmelia Ach., and Punctelia Krog, in Australasia. N.Z. J. Bot. 21: 397-420.

GALLOWAY, D.J. \& JAMES, P.W., 1986: Species of Pseudocyphellaria Vainio (Lichenes), recorded in Delise's "Histoire des Lichens: Genre Sticta" Nova Hedwigia 42: 423-490.

GALLOWAY, D.J., JAMES, P.W. \& WILKINS, A.L., 1983: Further nomenclatural and chemical notes on Pseudocyphellaria in New Zealand. Lichenologist 15: 135-145.

GIBLIN, R.W., 1928: THE EARLY HISTORY OF TASMANIA. THE GEOGRAPHICAL ERA 1642-1804. Methuen, London: 102-136.

HALE, M.E., 1987: A monograph of the lichen genus Parmelia Acharius sensu stricto (Ascomycotina:
Parmeliaceae). Smiths Contr. Bot, 66: 1-55.

HOLMGREN, P.K., KEUKEN, W. \& SCHOFIELD E.K., 1981: INDEX HERBARIORUM. Seventh edition. Bohn, Scheltema \& Holkema, Utrecht.

HOOKER, W.J., 1842: On Cenomyce retipora. Hook Lond. J. Bot. I: 292-294.

IØRGENSEN, P.M. \& JAMES, P.W., 1983: Studies on some Leptogium species of western Europe. Lichenologist 15: 109-125.

KANTVILAS, G., 1983: A brief history of lichenology in Tasmania. Pap. Proc. R. Soc. Tasm. 117 41-51.

KANTVILAS, G. \& JAMES, P.W., 1987: The macrolichens of Tasmanian rainforest: key and notes. Lichenologist 19: 1-28.

KANTVILAS, G, JAMES, P.W. \& JARMAN, S.J., 1985: Macrolichens in Tasmanian rainforests. Lichenologist 17: 67-83.

LABILLARDIERE, M. [J.-J.H.] de, 1800: VOYAGE IN SEARCH OF LA PÉROUSE PERFORMED BY ORDER OF THE CONSTITUENT ASSEMBLY, DURING THE YEARS 1791, 1792, 1793, AND 1794. Two volumes. John Stockdale, London.

LABILLARDIËRE, J.-J.H, de, 1804-1806 [1807]: NOVAE HOLLANDIAE PLANTARUM SPECIMEN. Two vols. Dominae Huzard, Paris.

MARTIN, W., 1962: Notes on some New Zealand species of Cladonia with descriptions of two new species and one new form. Trans. $R$. Soc. N.Z. (Bot.) 2: 39-44.

NELSON, E.C., 1974: The locations of collection and collectors of specimens described by Labillardière in "Novae Hollandiae Plantarum Specimen" - additional notes. Pap. Proc. $R$. Soc. Tasm. 108: 159-170.

NELSON, E.C., 1975: The collectors and type locations of some of Labillardière's "Terra Van-Leuwin" (Western Australia) specimens. Taxon 24: 319-336.

STAFLEU, F.A., 1967: ADANSON, LABLLLARDIĖRE, DE CANDOLLE INTRODUCTIONS TO FOUR OF THEIR BOOKS REPRINTED IN THE SERIES HISTORIAE NATURALIS CLASSICA. J. Cramer, Lehre.

STAFLEU, F.A. \& COWAN, R.S., 1979: TAXONOMIC LITERATURE. Volume II, H-LE. Bohn, Scheltema \& Holkema, Utrecht.

STEINBERG, C.H., 1977; The collectors and collections in the Herbarium Webb. Webbia 32: $1-49$.

STEVENS, G.N., 1987: The lichen genus Ramalina in Australia. Bull. Br. Mus. nat. Hist. (Bot.) 16 $107-223$.

TIBELL, L., 1987: Australasian Caliciales. Symb. Bot. Upsal. 27: 1-279.

WETMORE, C.M., 1963: Catalogue of the lichens of T'asmania. Rev. Bryol. Lichénol. 32: 223-264.

WHITE, F.J. \& JAMES, P.W., 1985: A new guide to microchemical techniques for the identification of lichen substances. Bull. Br. Lich. Soc. 57 (suppl.): $1-41$.

(accepted 13 May 1988) 